\title{
Impact Of Hr Audit on an Educational Institute in Order to Gain Insight into the Present Scenario and Future Prospects So That It Can Set a Benchmark for Educational Sector
}

\author{
Ghazala Ishrat ${ }^{1}$, Javed Habib ${ }^{2}$ \\ ${ }^{1}$ (Department of Engineering and Technology, Jamia Millia Islamia, India) \\ ${ }_{2}^{2}$ (Deputy Manager, ikra India Ltd, India)
}

\begin{abstract}
In the changing economic and business environment, proper Human Resource Management has assumed a crucial role in the growth of the organization. It has become imperative to re-look at this most important asset of the organization.

The main objective behind this research was to gain in-depth knowledge of the Human Resource and the effectiveness of HR functions within an organization. The HR audit in University was planned to get a clear judgment about the overall status of most faculties/Departments and to find out whether existing systems and procedures are yielding desired result. This information will be an invaluable input while making strategic decisions. Scope of the HR Audit conducted in this paper was specified as under:-
\end{abstract}

1. Audit of the Functional Role of each department and faculty.

2. Audit of the Service Role Of the department/Faculty or unit.

3. Audit of the Compliance to established benchmarks.

4. Audit of the Strategic effectiveness of the department/faculty/unit.

5. Audit of the Financial Management of the department/faculty/unit.

The human resource audit involved examining current policies, practices and strategies of all the departments/faculties to verify the effectiveness and helping University to improve its productivity, transparency and efficiency. To conduct Human Resource Audit in University extensive study on various aspects related to faculties, students and staff were analyzed and studied through interviews of staff at various levels, observation of working of non teaching staff, taking responses from students and staff by questionnaire method and documents review at various levels.

The firsthand experience has helped us in our specialization in HR as this enhanced our prospective of thoughts. The concise suggestions/ recommendations emerged after in depth analysis and study will provide with a wide scope to understand the functions and mechanism of working in any organization.

When we started to work upon the topic 'Human Resource Audit in University 'we thought of getting innumerable insights, articles, extracts and relevant materials but to our extreme wonder this field has to be probed and explored further in details as very little is done in this area. As far as our collective perception is concerned, we relied upon the lines from 'Psalm of Life' by Longfellow.....

"Let us then be up and doing, With a heart for any fate; Still achieving, still pursuing; Learn to labor and to wait".

Keywords: HR Audit, Innovative Tool, Working of An University, Functional Role of each department and faculty, Service Role Of the department/Faculty or unit, Compliance to established benchmarks, Strategic effectiveness of the department/faculty/unit, Financial Management of the department/faculty/unit

\section{Human Resource Audit: An Introduction}

\section{Introduction}

All companies, organizations, institutions consist of people and are meant to serve the people with products and services. Humans, therefore, are not only the resources of organizations but are the main instrument of their progress. It is not enough to say 'people are our most precious asset or business is people. Instead we must say our company or organization (including its results) is a creation of our people.

On the philosophical plane, no one disputes such averments. But in practice, and often subconsciously, many see employees as one of the business inputs, as hindrance to progress. Except in the initial period of the village artisans, humans have not been fully valued for their creativity and creations. Most of them have been used to do particular jobs to keep the wheels turning or production flowing. Often questions are asked, 'how many hands have you' and rarely, someone enquires how many creative minds you have.

The machines suppressed men's minds and encouraged use of hands and muscles. It has been a continuous quest to replace human hands by machines, not so much for the comfort of man, but to get more obedient, more indefatigable, disposable instruments of production. 
Except in a few enlightened organizations the situation still continues. The managers lured by the programmable automatic machines giving predictable results or output, virtually ignore the tremendous latent human potential. It is also overlooked, that even if the whole organization is automated, the progress and competitiveness will still depend on the few people that are left.

Only organizations and countries that valued and respected the creativity and aspirations of humans, made a lasting impact. Unfortunately, the notion that employee qualities defy evaluation and measurements held back the development of tools of assessment. And in turn, the annual reports, balance sheets and statements of profit and losses, the documents that receive attention of top management, government agencies and the public hardly reflect true assessment of human assets and their contributions.This paper seeks to review the tools available for such an assessment, and to suggest refinements to make these tools readily usable.

\section{How Is The Hr Audit Conducted?}

The human resource audit is "a systematic, formal evaluation of all human resource policies and programs in an organization (Hercus and Oades 1982, p. 43), It may focus on such matters as (1) how well the HR departments present purpose and strategy support those of the organization, (2) how well the departments structure enhances its ability to function, and (3) how well staffing and policies of the department are compatible with its purpose in the organization (Fombrun et al., 1984). These issues are important because department efforts in such HR practice areas as recruitment, training, compensation, and benefits- among othersare tools for influencing "goodness of fit" between people and positions. In other words, each practice area is a long-term change strategy in its own right that helps match up what kind of work is being done and the kind of people available to do the work.

\section{(1) To carry out the role of auditor, HR planners}

1. Decide what to examine in an HR audit.

2. Tentatively decide how to conduct the audit by drafting a rough audit plan.

3. Select people to assist in the audit.

4. Collect background information on any or all of the following areas: (1) the HR department, the HR plan, or practice areas: (2) the organization: (3) linkages between the HR department and organization: or (4) specific issues to be investigated.

5. Finalize the audit plan.

1. Collect audit information, comparing what is (actual conditions) to what should be (criteria). For each discrepancy between what is and what should be, auditors try to determine (1)cause (what is the reason for the discrepancy)

2. Compile audit result and use them to identify present "strengths" and "weaknesses" of the HR department and pinpoint fruitful areas for long-term action in order to improve the existing status of the HR department.

3. These steps are illustrated schematically in Figure . In many respect, the HR audit is thus the personnel departments counterpart to organizational appraisal, undertaken prior to strategic planning (Prager and Shea (1983).s 


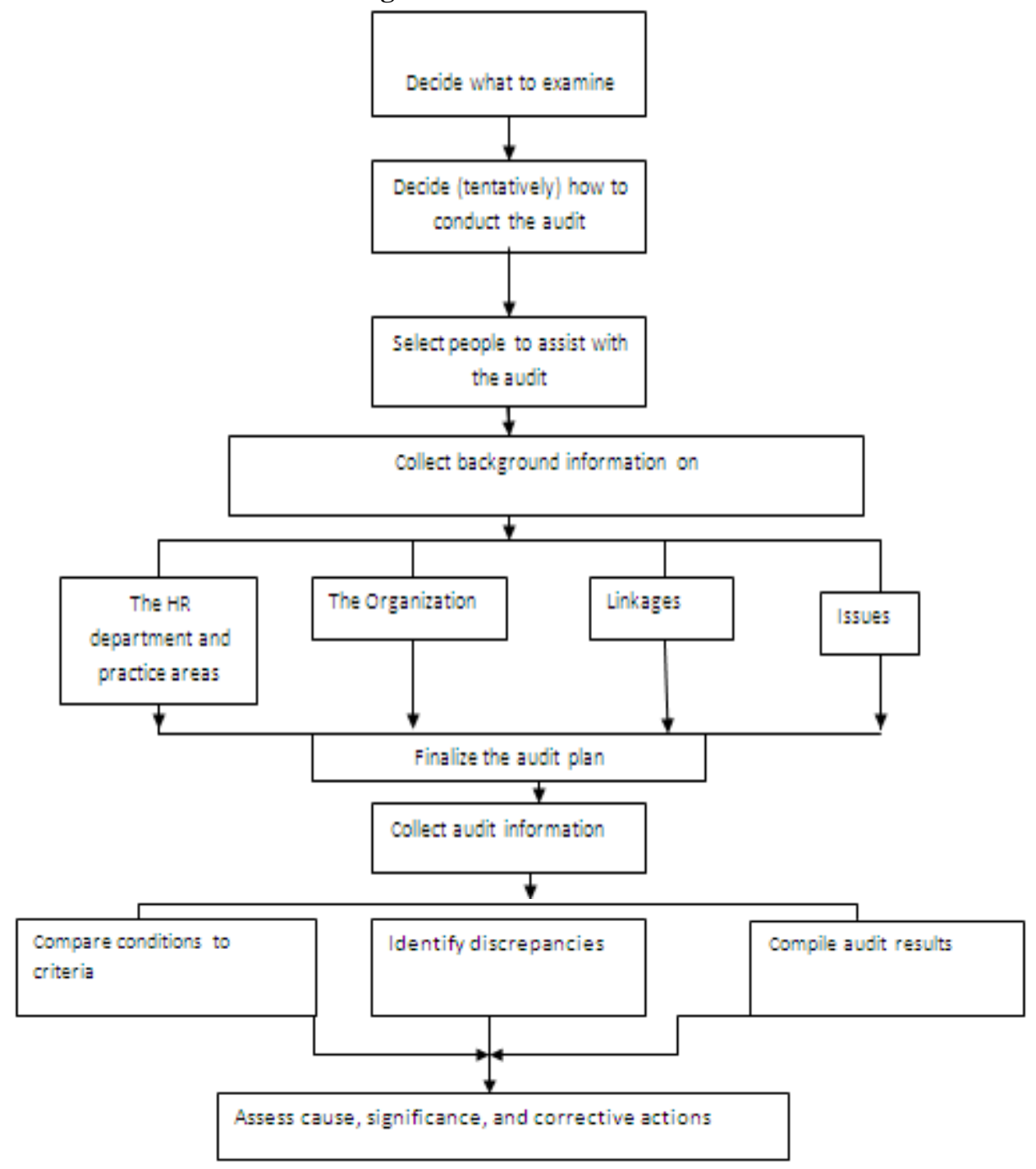

\section{University: An Overview Overview}

The University was founded by a visionary and an eminent personality, whose mission in life was to promote professional education among Indians. In the last 15 years or so, University has firmly established itself as a University of high repute providing professional and job-oriented education. Research has always been an important component of the academic activities in University from the very beginning. At present, 50 funded projects with a total outlay of Rs.7.50 crores are in progress. University unhesitatingly has branched off into the fields of Information Technology and Management Studies taking into account the demands of the job market.

It is one of the few Indian universities with complete computerization at all functional levels, including admissions, examinations, and administration, finance, library and hospital services. All the faculties have got a dedicated computer lab.. The University lays special emphasis on inculcating the feeling of brotherhood, spirit of accommodation and a healthy concern for social issues among the student fraternity. To this end, eminent scholars are invited to deliver lectures on matters of topical interest. The University community is committed to realize the dream of its founder, i.e., to see it as one of the premier educational institutions of the country. The governing bodies of the university are:

- The Society

- The Executive Council

- The Academic Council

- The Finance Committee

- The Planning and Monitoring Board

- Boards of Research Studies

- Faculty Committees

- Boards of Studies 


\section{B. Status}

The university has linkages with reputed institutions and organizations within the country and outside In recognition to the university's contribution to teaching and research, the National Assessment and Accreditation Council (NAAC), an autonomous body under the University Grants Commission. With 7 faculties and 24 departments, the university is offering 7 courses at Diploma level, 11 courses at Degree level and 22 courses at Post-graduate level in the on-campus mode of teaching. The university also offers Doctoral programme in 14 departments. The infrastructure and manpower are being consistently strengthened.

\begin{tabular}{|l|l|l|l|l|}
\hline \multicolumn{9}{|c|}{ Teaching staff } \\
\hline & Regular & Contractual & Temporary & Total \\
\hline Professor & 29 & & & 29 \\
\hline Ass. Prof. & 42 & - & - & 42 \\
\hline Asst. Prof. & 116 & - & - & 116 \\
\hline Others & $12+1$ & 01 & 04 & 18 \\
\hline Total & 200 & 01 & 04 & 205 \\
\hline
\end{tabular}

\begin{tabular}{|l|l|l|l|l|l|}
\hline \multicolumn{9}{|c|}{ Non Teaching Staff } \\
\hline & Regular & Contractual & Deputation/Adhoc & $\begin{array}{l}\text { Daily } \\
\text { wages }\end{array}$ & Total \\
\hline Group 'A' & 22 & 04 & 27 & - & 53 \\
\hline Group 'B' & 41 & 02 & 01 & - & 44 \\
\hline Group 'C' & 199 & 29 & 57 & - & 285 \\
\hline Group 'D' & 118 & 60 & 25 & 13 & 216 \\
\hline Total & 380 & 95 & 110 & 13 & 598 \\
\hline
\end{tabular}

\section{Students Admitted}

Details about the number of students admitted to various courses in a year are given below:

\begin{tabular}{|l|l|}
\hline Programme of study & Number of students \\
\hline Doctorial degree programmes & 146 \\
\hline Master's degree programmes & 642 \\
\hline Bachelor's degree programmes & 552 \\
\hline Diploma programme & 131 \\
\hline Pre-tib programmes & 20 \\
\hline Total & 1491 \\
\hline
\end{tabular}

Indian Students admitted in NRI/ Industry Sponsored Category

\begin{tabular}{|l|l|}
\hline PROGRAMME OF STUDY & NUMBER OF STUDENTS \\
\hline & NRIs/INDUSTRY SPONSORED \\
\hline Master's degree programmes & 70 \\
\hline Bachelor's degree programme & 80 \\
\hline Diploma degree programmes & 07 \\
\hline Total & 157 \\
\hline
\end{tabular}

\section{Human Resource Audit: University Audit Scope}

Scope of the HR Audit conducted in this Research was specified as under:-

1. Audit of the Functional Role of each department and faculty. This consists of the systems and procedures prevailing in the department/faculty, the deployment of the human resources within the department/Faculty and reportage and problem resolution methodologies.

2. Audit Of the Service Role Of the department/Faculty or unit

a) Tangibles such as facilities, equipment, people

b) Reliability of human resource with all their skills, competencies and individual personalities

c) Responsiveness of departmental management as compared to being 'reactive'

d) Assurance of quality

3. Audit of the Compliance to established benchmarks.

4. Audit of the Strategic effectiveness of the department/faculty/unit.

5. Audit of the Financial Management of the department/faculty/unit. 


\section{Methodology}

To conduct Human Resource Audit in University extensive study on various aspects related to faculties, students and staff were analyzed and studied. The process includes the following:

\section{a) Interview:}

Interviews and written surveys were found more appropriate than observation for collecting information on departmental strengths and weaknesses. Staff at different hierarchical levels and Students with different perspectives was sources of valuable information about what the department

(1) Has been doing well.

(2) Has not been doing well.

(3) Has been doing but should not be doing, and

(4) Has not been doing but should be doing.

\section{b) Document Review:}

Document reviews was not limited merely to publications intended for broad distribution, in fact informal communications between members of the department or between them and others in the organization was also examined. Examples of documents include department, budgets, letters, memoranda, and meeting agenda. We use content analysis to (1) Develop categories of topics or problems raised in the documents; (2) count the frequency of reference to each topic; (3) devise a checklist from the topics, giving priority to those frequently mentioned; (4) investigate how many times the same problems were raised in informal communication, what problems were apparently acted on and how many were not, and what results stemmed from auditor action and inaction.

\section{c) Questionnaire:}

The "organizational mirror" approach as described by Fordyce and Weil (171) was used for data gathering. It is a means for providing feedback to a group or department about how others perceive its activities or its performance. Hence, the "organization mirror" is useful because it reflects department "image". When applied to this HR audit, students and staff were asked questions as the following ones: (1) what do you think about the department generally? (2) In what ways do you feel that the department is functioning well? What are its present strengths? (3) In what ways do you feel that the department could improve its usefulness? What are its present weaknesses? (4) How do you feel the department could help your part of the organization improve operations in line with long-term strategic plans? Answers to Questionnaires used for students and staff members were then analyzed, placed in categories developed through content analysis and used as the basis for subsequent conclusion.

\section{d) Sampling:}

Extensive survey of students, staff, non-teaching staff was carried out by means of informal interactions, observation and questionnaire methods. Questionnaire was also used for this purpose.

\section{e) Paper Preparation:}

Information gained from above mentioned steps was studied and analyzed in details to formulate recommendations of this paper. Beside this discussions were also held on the Journals, annual reports and other references received during the process proved to be a great boon in collecting the data. Information through internet also helped in contributing towards this project.

\section{Conclusion}

Like the Alice in 'Alice in Wonderland', one door led to one information to another and one experience to other. We have seen and felt various facets that opened more avenues for us than to converge us to destination. As unexpected conclusion is more a part of learning than recommendation. Sometimes working for implementation part is like predicting the future and the more we went in in-depth, the more stimulated we got to get the golden keys.

The major learning as a part of conclusion are :

(a) HR audit helps to link the long term purpose, goals and objectives of the HR function/HR plans.

(b) It also examines what people are presently doing in their jobs in the organization.

(c) Examines what kinds of people are doing the work at present.

(d) Analyze the present strengths and weaknesses.

(e) Identify true trends and its likely impacts.

(f) Estimate the no. of people and jobs needed to achieve the objective/goal of a plan(s).

(g) Compare present and future jobs/people/HR practices. 
(h) Implement HR strategy and monitor whether HR strategy will work, is working and has worked.

As a part of our personnel learning we learnt more than expected. We got a firsthand insight of the real work as carried by the Personnel Department of a deemed university. The firsthand experience has helped us in our specialization in HR as this enhanced our prospective of thoughts. The concise suggestions/ recommendations emerged after in depth analysis and study will provide with a wide scope to understand the functions and mechanism of working in any organization.

\section{List Of Abbreviations Used}

$\begin{array}{ll}\text { PRO } & \text { Public Relation Officer } \\ \text { AICTE } & \text { All India Council of Technical Education } \\ \text { UGC } & \text { University Grants Commission } \\ \text { CFA } & \text { Chief Financial Officer } \\ \text { OSD } & \text { Officer on Special Duty } \\ \text { JE } & \text { Junior Engineer } \\ \text { SOP } & \text { Standard Operating Procedure } \\ \text { HR } & \text { Human Resource } \\ \text { OHP } & \text { Over-Head Projector } \\ \text { HoD } & \text { Head of Department } \\ \text { CCTV } & \text { Closed Circuit Television } \\ \text { MBA } & \text { Master of Business Administration } \\ \text { LCD } & \text { Liquid Crystal Display } \\ \text { INC } & \text { Indian Nursing Council } \\ \text { NPA } & \text { Non-Practicing Allowance } \\ \text { NAAC } & \text { National assessment and Accreditation Council } \\ \text { JH } & \text { University } \\ \text { AMC } & \text { Annual Maintenance Contract } \\ \text { LTC } & \text { Leave Travel Concession } \\ \text { HRA } & \text { House Rent Allowance } \\ \text { ACR } & \text { Annual Confidential Report } \\ \text { AE } & \text { Assistant Engineer } \\ \text { MoU } & \text { Memorandum of Understanding } \\ \text { AC } & \text { Air Conditioner } \\ \text { CDRI } & \text { Central Drug Research Institute } \\ \text { NBRI } & \text { National Botanical Research Institute } \\ \text { ITRC } & \text { Indian Toxicology Research Centre } \\ \text { CIF } & \text { Central Instrumentation Facility } \\ \text { BCA } & \text { Bachelor in Computer Application } \\ \text { MCA } & \text { Master in Computer Application } \\ & \\ & \end{array}$

\section{Recommendations}

\section{a) Administration}

1. Specific charter of duties for Security Personnel should be made available to Security supervisor and should be read, understood and signed by all the security staff at the time of taking over the duty.

2. Mock exercises should be conducted regularly to check response and serviceability of fire fighting capabilities/equipments

3. The EPBAX operators should be shifted to entrance of the main block so that they can perform the dual role of operator and receptionist.

4. There should be Job enlargement of PRO by delegating more responsibilities e.g. transport section/management and reception/operation of EPBAX .

5. There is a strong requirement of a database management system in the academics section as it has to deal with huge amount of data relating to students and staff. This would help in generating ad- hoc reports as and when required by UGC/AICTE and control delay in publication of Annual Report of University.

6. University should issue a letter for delegation of financial powers to various CFAs as the earlier letter on the delegated financial powers has expired on 31st March 2006 (discussion with staff)

7. There is a requirement of issuing detailed instructions on utilization of delegated financial powers by various CFAs and training on procurement procedures (observation of the audit team).

8. The system of allotment and expenditure of funds needs to be streamlined (suggestion from the audit team).

9. A formal system of monitoring of Probation period should be instituted. 
10. The need for a formal system of Induction training for the employees was strongly felt so as to acquaint them with the goals/objectives/vision of University so that they can contribute efficiently to achieve the same.

11. A detailed job description should be created for every post of University

12. An employee handbook should be published which includes various entitlements, rules/regulations governing these entitlements and forms for claims.

13. The turnover data of employees should be analyzed periodically and a system of formal exit interview should be instituted

14. With the help of University intranet a system should be instituted so that the employees have an access to the limited portion of their dossiers maintained at Establishment section to know the training/courses recorded gaps in Appraisal form etc and students should also be allowed to access e-governance system being installed to know curriculum, schedules, performance etc.

15. A formal system of redress of grievances of employees should be established with the system of feedback to aggrieved employee at every stage of processing of complaint

16. User satisfaction in terms of electrical and water supply should be increased. A separate complaint section should be established to register and monitor the complaints and action should be taken within 48 hours of lodging the complaints

17. The post of OSD should be filled by an Executive engineer at the earliest

18. The craftsmen posted with estate officer, JE (civil and electrical) should be merged under one engineer to increase efficiency .

19. There is a requirement of separate HR department in University.

\section{Points Common To All The Faculties}

1. A training programme for support Staff should be organized to acquaint them with operations of latest office equipments to improve efficiency

2. Wi-Fi connectivity and online system of information dissemination be implemented in all the faculties.

3. Charter of duties of teaching and non teaching staff should be available in all the faculty offices and updated regularly .

4. Standard Operating Procedure (SOP) with detailed actions to be initiated in different contingencies should be readily available in the office and regularly updated.

5. Extraction of information from the staff/employees of University was very difficult for the audit team, which signifies lack of transparency in the system. (observation by HR Audit team)

6. Induction training for all the new appointments should be conducted centrally as well as at departmental level.

7. Cleaning staff should be supervised effectively and local supervision should be entrusted at faculty level.

\section{Faculty Of Allied Health Sciences}

8. There is a requirement of 05 Professors, 07 Associate Professors and 09 Assistant Professors, to maintain student teacher ratio of 1:15 according to UGC norms.

9. The computer lab should be made functional by appointing computer trainer to students since 18 computers are lying unused for quite a long time. 2-4 OHPs should be provided to the department.

10. Library should be maintained with sufficient number of books. A section of library should be made as reading room for students.

11. A syllabus completion report should be submitted to the HoD before the end of each semester.

12. MoU should be established with hospitals for clinical postings of students.

13. Permanent faculty should be appointed in the department of clinical research as the department has six guest faculties and no permanent faculty.

14. Presently the Department of Paramedical sciences does not have a HoD.

15. There should be separate labs for each course like hematology, pathology etc

\section{Department Of Management Studies}

16. Vacant positions should be filled by new appointments of 9 Assistant professors, 7 Associate Professors and 5 Professors so as to maintain the proper hierarchy level according to UGC norms.

17. Lesson plan should be prepared by the faculty members and be submitted to the HoD at beginning of the semester

18. Case study material provided to students should be updated to bring in the new developments and recent trends in the market .

19. Proper ergonomic and gender catering environment should be provided for the staff and students.

20. Industrial exposure to management students should be increased. 
21. Permanent faculty for financial management should be appointed.

22. CCTV cameras should be installed in the classrooms as well as in the corridors for security and monitoring.

23. Specific guidelines should be laid for the conduct of Sessionals.

24. Proper feedback should be taken from the students about teaching faculty by the HoD.

25. Departmental library should also be available for MBA students. Presently the facility is offered to PhD students only.

26. Prior information of at least 24 hrs should be given in case of shifting of lectures.

27. Proper system of allotment of classes should be installed.

\section{Department Of Information Technology}

28. The shortage of 6 Assistant professors 12 Associate Professors and 5 Professors in the department should be met.

29. B.Tech. 1st yr students should also be provided with LCDs and laptops easily

30. Canteen should be renovated. Proper seating arrangement should be made

31. HODs should ensure that classes are efficiently and effectively held.

32. Required software should be installed and adequate number of computer terminals should be setup.

\section{Faculty Of Religious Studies}

33. There is over staffing in the faculty. The surplus staff can be utilized for administrative and other research work.

34. One of the ways of optimizing the student-teacher ratio can be to introduce B.A programme

\section{Faculty Of Nursing}

35. There is a shortage of teaching staff in the faculty. There is a requirement of at least six clinical instructors.

36. To meet the INC norms, more labs need to be setup in the faculty. This can also be achieved by purchase of required equipments to be placed in the available space.

37. The library can be updated with online journals from CINHAL.

\section{Faculty Of Science}

38. The department of bio-technology with uninterrupted power supply should be provided especially in the tissue culture lab

39. Industrial visits to various state and national level institutes, research centres and biotech parks should be conducted for students.

40. Teachers should be trained to inculcate a practice of correlating the theoretical aspects with practical implications.

41. A trained instructor should be provided to the students of the Department of Chemistry so that students don't have to go for hit and trial method of conducting experiments.

\section{Faculty Of Pharmacy}

42. There is a shortage of teaching staff in the faculty. The current student-teacher ratio of 1:26 needs to be optimized by hiring more teachers.

43. The computer lab should be made functional and the computer terminals should be upgraded and the student-computer ratio of $4: 1$ should be maintained .

44. There is a need of setting up a digital library.

45. The classroom furniture needs to be replaced with new ones.

\section{Faculty Of Medicine}

46. NPA @ 25\% of the basic should be provided to the doctors posted as faculty .

47. MoU with the nearest hospitals should be signed. The standard of University Hospital should be improved.

48. Suitable financial powers/allotment of funds should be made to the head of departments to keep maximum serviceability of lab equipments. 